\title{
Targeted cytotoxic bombesin analog AN-215 effectively inhibits experimental human breast cancers with a low induction of multi-drug resistance proteins
}

\author{
Jörg B Engel, Andrew V Schally, Gabor Halmos, Benjamin Baker, Attila Nagy \\ and Gunhild Keller
}

Endocrine, Polypeptide and Cancer Institute, Veterans Affairs Medical Center and Section of Experimental Medicine, Department of Medicine, Tulane University School of Medicine, New Orleans, Louisiana 70112, USA

(Requests for offprints should be addressed to A V Schally, VA Medical Center, 1601 Perdido St, New Orleans, LA 70112-1262, USA; Email: aschally@ tulane.edu)

\begin{abstract}
The cytotoxic analog of bombesin (BN)/gastrin releasing peptide (GRP) AN-215 consisting of 2-pyrrolinodoxorubicin (AN-201), a superactive derivative of doxorubicin linked to a bombesin analog carrier, displays a high affinity to BN/GRP receptors and can be targeted to tumors that express these receptors. We evaluated the antitumor effect and the toxicity of AN-215 in 5 human breast cancer cell lines xenografted into nude mice. In addition, we measured the mRNA expression of multi drug resistance protein 1 (MDR-1), multi drug resistance related protein 1 (MRP-1) and breast cancer resistance protein (BCRP) by real-time PCR analysis after treatment with AN-215. All five cell lines expressed BN/GRP receptors, and AN-215 significantly $(P<0.05)$ inhibited tumor growth in all models, while its cytotoxic radical AN-201 had no significant effect in four models. In MX-1 tumors, AN-201 had a significantly weaker antitumor effect than AN-215. The effect of AN-215 was nullified by a blockade of BN/GRP receptors with a bombesin antagonist. Low or no induction of MDR-1, MRP-1 and BCRP occurred after treatment with AN-215. In conclusion, targeted chemotherapy with the cytotoxic BN/GRP analog AN-215 strongly inhibits breast cancers that express BN/GRP receptors and might provide a new treatment modality for mammary carcinoma.
\end{abstract}

Endocrine-Related Cancer (2005) 12 999-1009

\section{Introduction}

Breast cancer is the most common malignancy among women in the United States and Europe and ranks second as a cause of cancer-related deaths (Bray et al. 1995, Hortobagyi 2003, Jemal et al. 2005). Thus, in 2005, an estimated 210000 new cases of breast cancer with about 40000 deaths are expected to occur in the USA (Jemal et al. 2005). Most patients succumb to this disease not because of the primary cancer, but because of metastases. In spite of the use of endocrine therapy, systemic chemotherapy and novel approaches such as trastuzumab (Herceptin), an antibody against human epidermal growth factor receptor 2 (HER-2), metastatic disease remains generally incurable with a median survival time of 2 to 3 years (Powles et al. 1980, Todd et al. 1983, Clark et al. 1987, Greenberg et al. 1996, Osborne 1998). Therefore, it is mandatory to develop novel, more effective treatment strategies with low toxicity for the treatment of breast cancer.

The discovery of specific molecular characteristics of malignant cells prompted the development of a new class of drugs known as targeted therapeutics. This new class of antitumor agents includes antibodies against surface structures on tumor cells, such as trastuzumab (Baselga et al. 1996), and hybrid molecules consisting of receptor-specific ligands linked to toxins, radionuclides or chemotherapeutic agents (Magrath 1994, Abou-Jawde et al. 2003, Trail et al. 2003). High-affinity receptors for peptide hormones 
expressed on malignant cells can be targeted by cytotoxic hormone analogs consisting of a peptide carrier linked to an antineoplastic agent (Nagy et al. 1996, Schally \& Nagy 1999, 2003, 2004). The direct delivery of the cytotoxic radical to the malignant tissue is expected to result in a higher antitumor effect with a reduced systemic toxicity and may overcome chemoresistance of cancer cells. Multidrug resistance (MDR) of cancer cells to a variety of antitumor agents remains a major problem in chemotherapy. The ATP-dependent membrane transporter protein, p-glycoprotein (pGP), the product of the MDR-1 gene, and the recently discovered MDR protein 1 (MRP-1) mediate the increased extracellular efflux of chemotherapeutic agents (Juliano \& Ling 1976, Cole et al. 1992). Breast cancer resistance protein (BCRP) is another overlapping but distinct type of MDR, based on drug efflux (Ross et al. 1999). The expression of mRNA for MDR-1 has been detected in about $50 \%$ of untreated breast cancer samples (Keith et al. 1990) and induction of the MDR-1 protein pGP was detected in breast cancer specimens after treatment with doxorubicin (Schneider et al. 1989). MRP-1 immunoreactivity was found in $34-80 \%$ of primary breast carcinomas (Nooter et al. 1997, Filipits et al. 1999). MRP-1 overexpression seems to be associated with a poor prognosis (Nooter et al. 1997, Ito et al. 1998, Filipits et al. 1999). Chemotherapeutic drugs targeted directly to tumor cells could overcome MDR based on transmembrane efflux, as the local concentration of the antitumor agent is increased.

Specific receptors for bombesin (BN)-like peptides, such as the gastrin-releasing peptide receptor (GRPR), the neuromedin $\mathrm{B}$ receptor (NMBR) and the bombesin receptor subtype 3 (BRS-3), have been found in various human cancer specimens and cancer cell lines (Halmos et al. 1995, Wang et al. 1996, Markwalder \& Reubi 1999, Sun et al. 2000, Schally et al. 2001). The presence of binding sites for BN/GRP in human breast cancer specimens was established by our group (Halmos et al. 1995) and it has recently been reported that the GRPR, which binds bombesin with high affinity, was expressed in 29 of 46 human invasive ductal breast carcinomas (Gugger \& Reubi 1999). In addition, the lymph node metastases from GRPRpositive tumors were all found to be GRPR positive, whereas in surrounding lymphoreticular tissue no receptor expression could be found (Gugger \& Reubi 1999). In several clinical studies, primary breast cancers and their lymph node metastases were successfully detected using GRPR scintigraphy (Van de Wiele et al. 2000, Scopinaro et al. 2002, Soluri et al. 2003). Therefore, GRPR scintigraphy could be used to select patients who may respond to therapy targeted to BN/GRP receptors. These findings suggest that $\mathrm{BN} / \mathrm{GRP}$ receptors on breast cancer are a potential target for therapy with cytotoxic bombesin analogs.

The cytotoxic analog of bombesin, AN-215, developed in our laboratory, consists of a highly potent derivative of doxorubicin (DOX), 2-pyrrolino-DOX (AN-201) (Nagy et al. 1996), linked covalently to a bombesin-like carrier octapeptide Gln-Trp-Ala-ValGly-His-Leu- $\psi\left(\mathrm{CH}_{2}-\mathrm{NH}\right)-\mathrm{Leu}-\mathrm{NH}_{2}$ (RC-3094) (Nagy et al. 1997). AN-215 shows high affinity to GRPR and retains the antiproliferative activity of its cytotoxic moiety, AN-201. AN-215 effectively inhibited growth of experimental gastric and prostatic cancers, small cell carcinomas and glioblastomas (Nagy et al. 1997, Schally 2004).

This study was designed to evaluate the therapeutic efficacy and the toxicity of the cytotoxic bombesin analog AN-215 and its effect on MDR-1, MRP-1 and BCRP expression in experimental models of human breast cancer in vivo.

\section{Materials and methods \\ Peptides and cytotoxic radical}

The cytotoxic radical 2-pyrrolino-DOX (AN-201), the bombesin analog carrier RC-3094, the cytotoxic bombesin analog $\mathrm{AN}-215$ and the bombesin antagonist RC-3095 were synthesized in our laboratory as described (Nagy et al. 1996, 1997). Before intravenous (i.v.) injection, the compounds were dissolved in $5 \%(\mathrm{w} / \mathrm{v})$ aqueous D-mannitol solution (Sigma, $\mathrm{St}$ Louis, MO, USA).

\section{Cell lines}

The estrogen-independent human breast cancer cell line MDA-MB-231 is a poorly differentiated mammary adenocarcinoma derived from a pleural effusion of a 51-year-old Caucasian female with metastatic adenocarcinoma of the breast (Cailleau et al. 1974). The estrogen-independent human breast cancer cell line MDA-MB-468 is a poorly differentiated mammary adenocarcinoma derived from a pleural effusion of a 51-year-old African American female with metastatic adenocarcinoma of the breast (Cailleau et al. 1978). The estrogen-independent MDA-MB-435 human breast cancer cell line was established from the pleural effusion of a 31-year-old Caucasian female with metastatic ductal adenocarcinoma (Cailleau et al. 1978). The estrogen-independent human breast cancer 
cell line DU-4475 originated from a cutaneous metastatic nodule of a 70-year-old Caucasian female (Langlois et al. 1979). All cell lines were obtained from the American Type Culture Collection (ATCC, Manassas, VA, USA).

The cells were grown at $37^{\circ} \mathrm{C}$ in a humidified $95 \%$ air : $5 \%$ carbon dioxide atmosphere, passaged weekly and routinely monitored for mycoplasma contamination using a detection kit (Boehringer Mannheim, Mannheim, Germany). All culture media were purchased from Gibco (Grand Island, NY, USA).

The hormone-independent DOX-resistant human breast cancer xenograft $\mathrm{MX}-1$, originating from a surgical explant, was kindly donated by Dr Richard Camalier (NCI, Frederick Cancer and Development Center, Frederick, MD, USA). Tumors were maintained in donor animals.

\section{Animals}

Five- to six-week-old female athymic nude mice $(\mathrm{Ncr} n u / n u)$ were obtained from the National Cancer Institute (NCI, Bethesda, MD, USA). The animals were housed in sterile cages under laminar flow hoods in a temperature-controlled room with a 12-h light/12-h darkness schedule. They were fed autoclaved chow and water, which were available ad libitum.

\section{Experimental protocol}

Cells of each cell line, except MX-1 and MDA-MB-435 human breast cancers, growing exponentially were implanted into 5 female nude mice by subcutaneous injection of $10^{7}$ cells into both flanks. Tumors resulting after 4 weeks in donor animals were aseptically dissected and mechanically minced. In all experiments except experiment 3, pieces of tumor tissue, about $3 \mathrm{~mm}^{3}$, were transplanted subcutaneously (s.c.) into the experimental animals by a trocar needle. In experiment 3, MDA-MB-435 cells $\left(2 \times 10^{6}\right)$ were directly injected into the mammary fat pad of experimental animals.

Tumor volume $($ length $\times$ width $\times$ height $\times 0.5236)$ and body weight were measured weekly. The total leukocyte count (WBC) was determined with the Unopette microcollection kit (Becton Dickinson, Franklin Lakes, NJ, USA). The tumor doubling time (TDT) was calculated according to the following formula: (days of treatment $\times$ LOG10(2))/(LOG10 (final tumor volume)-LOG10(initial tumor volume)). At the end of each experiment, mice were killed under anesthesia, tumors were excised and weighed, and necropsy was performed. Tumor specimens were snap frozen and stored at $-70^{\circ} \mathrm{C}$. All experiments were performed in accordance with the institutional ethical guidelines for the care of animals and were essentially in agreement with UKCCCR guidelines (1998) for the welfare of animals in experimental neoplasia. Tumor weights never exceeded $10 \%$ of the animals' body weight. The Institutional Animal Care and Use Committee reviewed the protocol for the animal experiments and gave full approval.

\section{Single dose treatment}

Animals bearing MDA-MB-231 (experiment 1), DU4475 (experiment 2), MDA-MB-435 (experiment 3) or MX-1 (experiment 4) tumors received the following treatment as a single injection into the jugular vein: group 1 (control) was given vehicle solution (5\% mannitol), group 2 received the cytotoxic analog $\mathrm{AN}-215$ at $200 \mathrm{nmol} / \mathrm{kg}$, and group 3 was treated with the cytotoxic radical AN-201 at $200 \mathrm{nmol} / \mathrm{kg}$.

In experiment 1 , three additional groups were included: group 4 was given an unconjugated mixture of the cytotoxic radical AN-201 and the bombesin analog carrier RC-3094 at $200 \mathrm{nmol} / \mathrm{kg}$, group 5 was injected with RC-3094 alone at $200 \mathrm{nmol} / \mathrm{kg}$, and group 6 received $200 \mu \mathrm{g}$ of the bombesin antagonist RC-3095 i.v. $15 \mathrm{~min}$ prior to the i.v. injection of cytotoxic analog AN-215 at $200 \mathrm{nmol} / \mathrm{kg}$.

\section{Multiple dose treatment}

Animals with MDA-MB-231 (experiment 5) tumors were treated twice with i.v. injections (day 1 and day 8). Group 1 received control, vehicle solution, group 2 was given $\mathrm{AN}-215$ at $150 \mathrm{nmol} / \mathrm{kg}$, and group 3 was injected with $\mathrm{AN}-201$ at $150 \mathrm{nmol} / \mathrm{kg}$.

Mice with MDA-MB-468 (experiment 6) tumors were also injected twice i.v. (day 1 and day 29). Group 1 received control, vehicle solution, group 2 was given $\mathrm{AN}-215$ at $200 \mathrm{nmol} / \mathrm{kg}$, and group 3 was injected with $\mathrm{AN}-201$ at $200 \mathrm{nmol} / \mathrm{kg}$.

\section{Receptor binding assay}

Binding characteristics of bombesin/GRPR on tumor membrane preparations from control animals and animals after treatment with AN-215 and AN-201 were determined by ligand competition assay using ${ }^{125}$ I-labeled $\left[\mathrm{Tyr}^{4}\right]$-bombesin. Preparation of tumor membrane fractions and receptor binding studies of $\mathrm{BN} / \mathrm{GRP}$ were performed as described previously (Halmos et al. 1994). 


\section{RNA isolation and reverse transcriptase-polymerase chain reaction (RT-PCR) analysis}

The methods for isolation of total RNA and RT-PCR for analysis of the expression of subtypes of BN/GRP receptors (GRPR, NMBR and BRS-3) have been reported (Kiaris et al. 1999). Ten microliter aliquots of the PCR products were separated on $1.8 \%$ agarose gel and visualized by ethidium bromide on an ultraviolet transilluminator. The MDA-MB-468 cell line is known to express all three bombesin receptor subtypes and was therefore taken as a positive control (Kahan et al.2000).

\section{Real-time PCR for MDR-1, MRP-1 and BCRP MRNA expression}

Total RNA was isolated from approximately $100 \mathrm{mg}$ tumor tissue for each sample according to the TRIReagent protocol (sigma). One microgram total RNA was subjected to reverse transcription with the Iscript cDNA synthesis kit (BioRad) following the manufacturer's protocol. Real-time PCR was employed to measure drug resistance gene expression using the SYBR Green system (BioRad). Primers for MDR-1 (sense $\quad 5^{\prime}$-TCT GGA GGA AGA CAT GAC CAG GTA-3'; antisense 5'-GGC ACC AAA ATG AAA CC T GAA TGT-3'), MRP-1 (sense 5'-AGA GAC AGC T CA GCA GCT CCT-3'; antisense 5'-GCC TTG TCA G CC TCC ATCAG-3'), BCRP (sense 5'-TATCAA TG G GAT CAT GAA ACC TGG-3', antisense 5'-GCG G TG CTC CAT TTA TCA GAA C- $3^{\prime}$ ) and $\beta$-actin (sense 5'-CTG GAA CGG TGA AGG TGA CA-3'; antisense 5'-AAG GGA CTT CCT GTA ACA ATG CA-3') were used to measure gene expression. The thermal cycling conditions comprised an initial denaturation step at $95^{\circ} \mathrm{C}$ for $3 \mathrm{~min}$, then 40 cycles of two-step PCR including $95^{\circ} \mathrm{C}$ for $15 \mathrm{~s}$ and $60^{\circ} \mathrm{C}$ for $1 \mathrm{~min}$. Data were collected during the $60^{\circ} \mathrm{C}$ annealing step and were further analyzed by the iCycler iQ Optical system software (BioRad). Real-time PCR efficiencies (E) for MDR-1 (target gene 1), MRP (target gene 2) and $\beta$-actin (reference gene) were calculated from the given slopes in the iCycler software according to the following equation: $\mathrm{E}=10^{[-1 / \text { slope }]}$ (Rasmussen 2001). Nine tumor samples from each experiment (3 control, $3 \mathrm{AN}-215$ and $3 \mathrm{AN}-201)$ were analyzed in triplicate. For the mathematical model used in this study it was necessary to determine the crossing points for the transcripts of each sample. Crossing points (CPs) are defined as the number of cycles at which the fluorescence rises appreciably above the background fluorescence. Using $\mathrm{CP}$ deviations $(\Delta \mathrm{CP})$ for control and treatment $\left(\mathrm{CP}_{\text {controls }}-\mathrm{CP}_{\text {treatment }}\right)$ of target and reference gene transcripts, quantification of the target genes in treated groups relative to the controls was performed using a mathematical model by Pfaffl (2001):

$$
\begin{aligned}
\text { Ratio }= & \left(\mathrm{E}_{\text {target }}\right)^{\Delta \mathrm{CP} \text { target (control-treatment): }} \\
& \left(\mathrm{E}_{\text {reference }}\right)^{\Delta \mathrm{CP} \text { reference (control-treatment })}
\end{aligned}
$$

\section{Statistical analysis}

Data are expressed as means \pm s.E. Differences between mean values were evaluated by two-tailed Student's $t$-test. $P<0.05$ was considered significant.

\section{Results}

\section{Anti-tumor effects of the cytotoxic bombesin analog $\mathrm{AN}-215$ in single dose application}

In experiments 1, 2 and 3, a single dose of AN-215 at $200 \mathrm{nmol} / \mathrm{kg}$ significantly inhibited $(P<0.05)$ the growth of MDA-MB-231, DU-4475 and MDA-MB435 cancers, as reflected by significant decreases in tumor volume and weight and significantly extended tumor doubling times $(P<0.05)$ (Fig. 1A-C, Table 1). Equimolar doses of AN-201 had no significant effects on the growth characteristics. In experiment 1 , a mixture of AN-201 and its bombesin analog carrier, RC-3094, and RC-3094 alone did not suppress tumor growth (Fig. 1A, Table 1). In this experiment, the effect of AN-215 could be nullified by injecting $200 \mu \mathrm{g}$ of the bombesin antagonist RC-3095 $15 \mathrm{~min}$ prior to the administration of AN-215. In experiment 4, the cytotoxic analog $\mathrm{AN}-215$ and the cytotoxic radical AN-201 at doses of $200 \mathrm{nmol} / \mathrm{kg}$ significantly $(P<0.01)$ inhibited the growth of MX-1 tumors for the first 28 days, while the tumors in the control group grew rapidly (Fig. 1D). Thus, the control animals had to be killed on day 29 because of a high tumor burden $\left(1695.3 \pm 246.1 \mathrm{~mm}^{3}\right)$. After treatment with AN-215, 8 of 10 animals became tumor-free, of which 5 redeveloped palpable tumors but 3 remained tumor-free until the end of the experiment (Fig. 1E). In the group treated with AN-201, the tumors of only 2 mice disappeared, but regrew in one animal before the experiment was terminated (Fig. 1E). At the end of the experiment on day 50, animals injected with AN-215 had a significantly $(P<0.05)$ smaller mean tumor volume $\left(493.8 \pm 188.3 \mathrm{~mm}^{3}\right.$ compared with $1261.7 \pm 258.0 \mathrm{~mm}^{3}$ ) than animals treated with an equimolar dose of AN-201 (Fig. 1D).

\section{Antitumor effects of the cytotoxic bombesin analog $\mathrm{AN}-215$ at multiple doses}

In experiment 5 , administration of $\mathrm{AN}-215$ at a dose of $150 \mathrm{nmol} / \mathrm{kg}$ on day 1 and day 8 significantly $(P<0.05)$ 

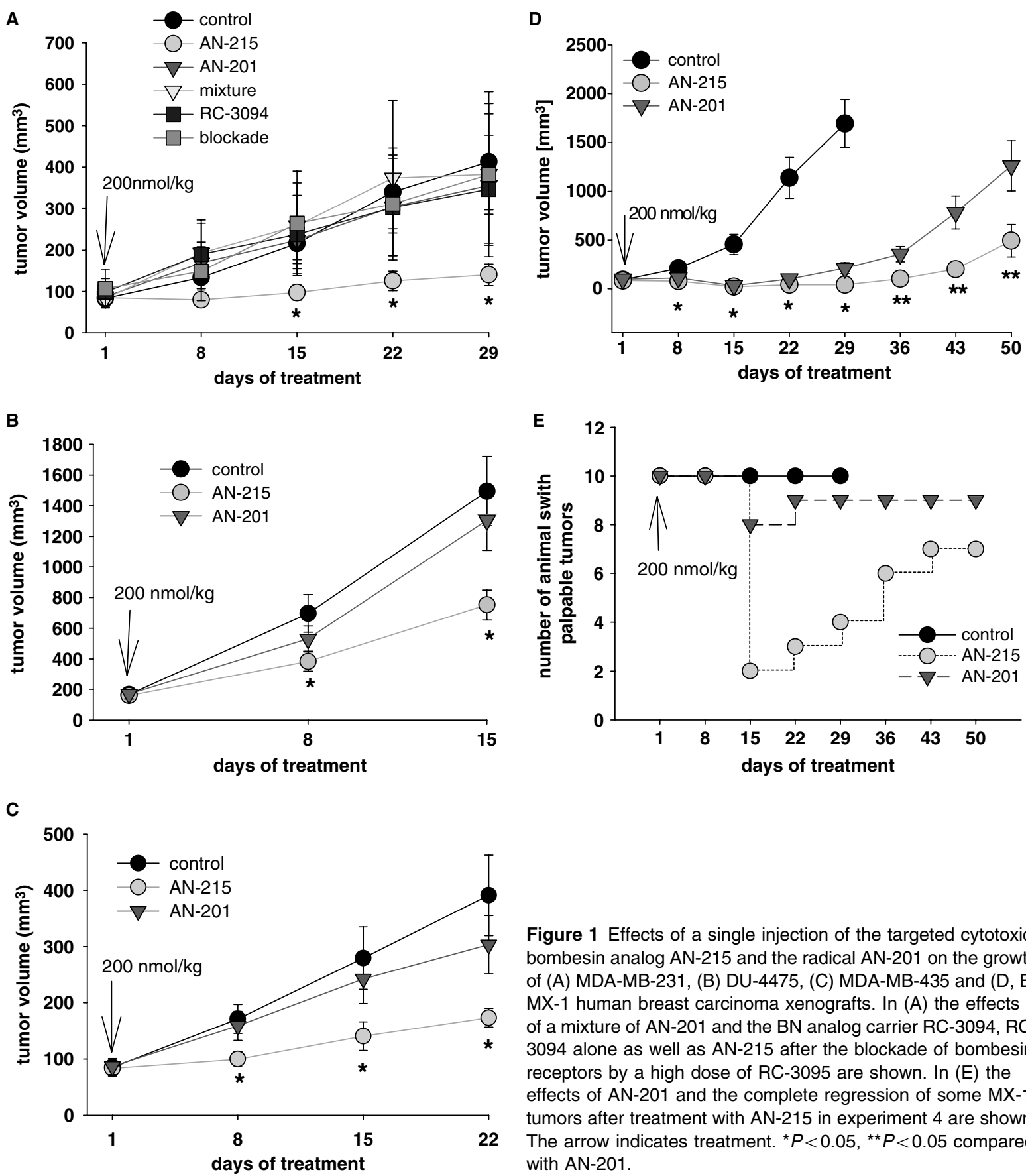

Figure 1 Effects of a single injection of the targeted cytotoxic bombesin analog $\mathrm{AN}-215$ and the radical $\mathrm{AN}-201$ on the growth of (A) MDA-MB-231, (B) DU-4475, (C) MDA-MB-435 and (D, E) MX-1 human breast carcinoma xenografts. In (A) the effects of a mixture of AN-201 and the BN analog carrier RC-3094, RC3094 alone as well as AN-215 after the blockade of bombesin receptors by a high dose of $\mathrm{RC}-3095$ are shown. In (E) the effects of $\mathrm{AN}-201$ and the complete regression of some MX-1 tumors after treatment with $\mathrm{AN}-215$ in experiment 4 are shown. The arrow indicates treatment. ${ }^{\star} P<0.05,{ }^{\star \star} P<0.05$ compared with AN-201.

inhibited the growth of MDA-MB-231 tumors from day 8 until the end of the experiment, when the final tumor volume and weight were $55 \%$ smaller than in controls. Tumor doubling time was also significantly $(P<0.05)$ prolonged by $\mathrm{AN}-215$. No significant effect on tumor growth was observed in animals treated with equimolar doses of AN-201 (Fig. 2A, Table 1). In

experiment 6, consecutive administration of $\mathrm{AN}-215$ at a dose of $200 \mathrm{nmol} / \mathrm{kg}$ on day 1 and day 29 significantly $(P<0.05)$ inhibited the growth of xenografts of the relatively slow-growing MDA-MB-468 cancer cell line. The final tumor volume was $71.5 \%$ smaller than in controls, and the tumor doubling time was significantly $(P<0.05)$ prolonged by $\mathrm{AN}-215$. The final tumor 
Table 1 Effects of therapy with targeted cytotoxic analog of bombesin AN-215 and its components on the growth of four human breast carcinoma lines xenografted into nude mice

\begin{tabular}{|c|c|c|c|}
\hline Treatment & $\begin{array}{c}\text { Tumor weight } \\
\text { (mg) (\% inhibition) }\end{array}$ & $\begin{array}{l}\text { Tumor doubling } \\
\text { time (days) }\end{array}$ & WBC on day 8 (cells $\left./ \mathrm{mm}^{3}\right)$ \\
\hline \multicolumn{4}{|c|}{ Experiment 1 (MDA-MB-231) } \\
\hline Control & $505.7 \pm 125.3$ & $14.6 \pm 2.0$ & $10175 \pm 248.0$ \\
\hline AN-215 & $187.7 \pm 42.0(62.9)^{\star}$ & $29.2 \pm 7.4^{*}$ & $8085 \pm 338.2$ \\
\hline AN-201 & $479.7 \pm 97.1(5.1)$ & $15.6 \pm 1.1$ & $6490 \pm 639.8^{*}$ \\
\hline Mixture & $469.0 \pm 272.9(7.3)$ & $20.5 \pm 3.0$ & N.D. \\
\hline RC-3094 & $475.2 \pm 183.7(6.0)$ & $17.1 \pm 1.7$ & N.D. \\
\hline Blockade & $461.8 \pm 221.0(8.7)$ & $18.8 \pm 3.1$ & N.D. \\
\hline \multicolumn{4}{|c|}{ Experiment 2 (DU-4475) } \\
\hline Control & $2105.4 \pm 301.7$ & $4.8 \pm 0.22$ & $9925.5 \pm 400.1$ \\
\hline AN-215 & $1245.4 \pm 113.8(40.7)^{\star}$ & $7.0 \pm 0.9^{*}$ & $7095 \pm 1008.7$ \\
\hline AN-201 & $1860 \pm 267.8(11.6)$ & $5.2 \pm 0.6$ & $5390 \pm 614.1^{\star \star}$ \\
\hline \multicolumn{4}{|c|}{ Experiment 3 (MDA-MB-435) } \\
\hline Control & $494.4 \pm 95.4$ & $11.8 \pm 0.9$ & $10037.5 \pm 609.8$ \\
\hline AN-215 & $272.9 \pm 31.1(44.8)^{\star}$ & $17.9 \pm 2.0^{*}$ & $8772.5 \pm 541.5$ \\
\hline AN-201 & $388.9 \pm 64.4(21.3)$ & $13.8 \pm 2.0$ & $6517.5 \pm 691.9^{\star *}$ \\
\hline \multicolumn{4}{|c|}{ Experiment 5 (MDA-MB-231) ${ }^{+}$} \\
\hline Control & $589.0 \pm 105.6$ & $9.8 \pm 1.1$ & $8442.5 \pm 939.2$ \\
\hline AN-215 & $263.3 \pm 53.3(55.3)^{\star}$ & $15.0 \pm 1.5^{*}$ & $6765 \pm 1083.8$ \\
\hline AN-201 & $498.8 \pm 141.2(15.3)$ & $10.7 \pm 3.2$ & $5142.5 \pm 853.7^{\star}$ \\
\hline \multicolumn{4}{|c|}{ Experiment 6 (MDA-MB-468) ${ }^{+}$} \\
\hline Control & $160.1 \pm 39.0$ & $34.5 \pm 5.6$ & $10367.5 \pm 449.9$ \\
\hline AN-215 & $50.6 \pm 5.1(68.4)^{\star}$ & $92.2 \pm 18.8^{*}$ & $9377.5 \pm 1834.3$ \\
\hline AN-201 & $116.4 \pm 38.1(27.3)$ & $68.4 \pm 20.8$ & $6875 \pm 1060.3^{*}$ \\
\hline
\end{tabular}

${ }^{+}$In experiment 5 and 6 the compounds were administered twice.

N.D., not determined.

${ }^{\star} P<0.05,{ }^{* *} P<0.01$ (two-sided Student's $t$-test).

weight was inhibited by $68.4 \%(P<0.05)$. No significant effect on tumor growth was observed in animals treated with equimolar doses of $\mathrm{AN}-201$ (Fig. 2B, Table 1).

\section{Side effects and toxicity}

AN-215 did not significantly lower the $\mathrm{WBC}$ in any experiment (Table 1). In all experiments, WBC was significantly $(P<0.05)$ decreased on day 8 by AN-201 at a dose of 200 or $150 \mathrm{nmol} / \mathrm{kg}$ (Table 1). In experiment 5, a second dose of AN-201 administered on day 8 significantly $(P<0.01)$ suppressed the WBC on day 15. In experiment 6 , a second dose of AN-201 at $200 \mathrm{nmol} / \mathrm{kg}$ administered on day 29 significantly decreased the WBC on day 36. In all experiments, a moderate weight loss occurred 8 days after the injection of AN-215 or AN-201, but weights normalized one week later. In experiments 2 and 3, AN-201 significantly $(P<0.05)$ lowered the body weight on day 8. AN-215 did not cause any statistically significant loss of body weight in any experiment. The overall mortality was $7 \%$ in control animals, $6.8 \%$ after treatment with $\mathrm{AN}-215$ and $15.8 \%$ in animals treated with AN-201.

\section{In vivo expression and characteristics of BN/GRP receptors}

Using gene-specific primers, the expression of mRNA for 3 established subtypes of $\mathrm{BN}$ receptors was investigated by RT-PCR in MDA-MB-231, MDA-MB-435, DU-4475 and MX-1 tumors (Fig. 3). mRNAs were detected for all three receptor subtypes in all cell lines investigated. MDA-MB-468 is known to express all 3 receptor subtypes and was therefore used as a positive control (Kahan et al. 2000).

Specific high-affinity binding sites for ${ }^{125}$ I-labeled $\left[\mathrm{Tyr}^{4}\right]-\mathrm{BN}$ were detected on membrane fractions of MDA-MB-231, MDA-MB-435, DU-4475, MX-1 and MDA-MB-468 breast cancers (Table 2). AN-215 administered as one dose of $200 \mathrm{nmol} / \mathrm{kg}$ or as two consecutive doses of 200 and $150 \mathrm{nmol} / \mathrm{kg}$ did not affect the binding characteristics of $\mathrm{BN} / \mathrm{GRP}$ receptors in DU-4475 and MDA-MB-231 breast cancers respectively (data not shown). 
A

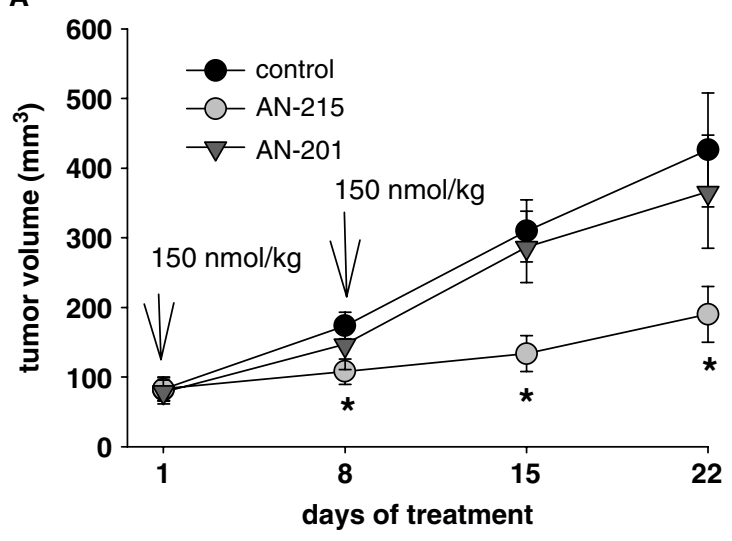

B

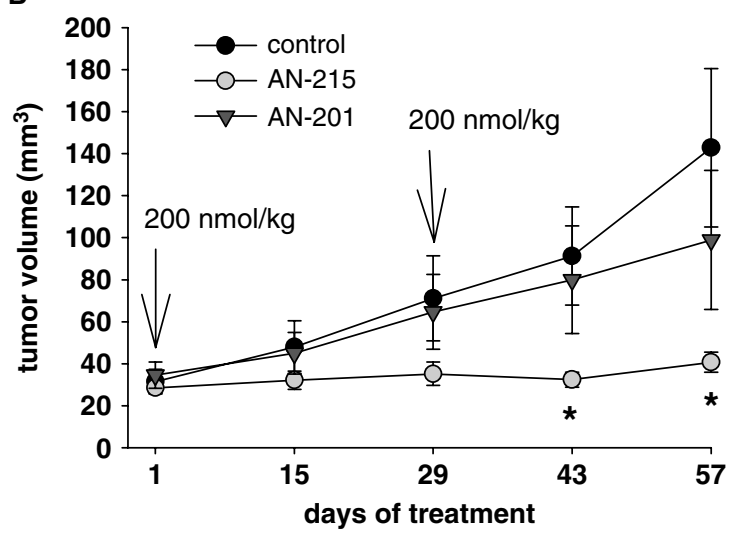

Figure 2 Effects of two consecutive injections of the targeted cytotoxic bombesin analog $\mathrm{AN}-215$ and the cytotoxic radical AN-201 on the growth of (A) MDA-MB-231 and (B) MDA-MB-468 human breast carcinoma xenografts. The arrows indicate treatment. ${ }^{*} P<0.05$ compared with controls.

\section{MDR-1, MRP-1 and BCRP mRNA expression by real-time PCR}

mRNA for MDR-1, MRP-1 and BCRP was detected in MDA-MB-231, MDA-MB-435 and DU-4475 breast cancers. On ethidium bromide gels, a single band of the expected size for each gene was seen. The PCR products were of the expected sizes of $95 \mathrm{bp}$ for MDR-1, $127 \mathrm{bp}$ for MRP-1, $140 \mathrm{bp}$ for BCRP and 140 bp for $\beta$-actin (Fig. 4). The primers did not amplify any product using genomic DNA or the RT product. The efficiencies (E) were 1.989 for MDR-1, 1.999 for MRP-1, 1.987 for BCRP and 1.997 for $\beta$-actin. In MDA-MB-231, MDA-MB-435 and DU-4475 cancers, a single dose of $200 \mathrm{nmol} / \mathrm{kg}$ of $\mathrm{AN}-215$ or AN-201 caused a similar, weak induction (1- to 1.8-fold) of MDR-1 gene expression. In MDA-MB-231 tumors, MRP-1 levels were slightly higher after therapy with AN-215 (3.1- vs 2.1-fold), and BCRP expression in this cell line was also higher after administration of AN-201 (1.4- vs 1-fold). In MDA-MB-435 cancers, expression levels of mRNA for MRP-1 and BCRP were slightly higher after treatment with AN-215 (respectively 2.6- vs 1.7-fold and 3.0- vs 0.9-fold). MRP-1 and BCRP mRNA levels of DU-4475 cancers did not increase after treatment with AN-215 and AN-201.

\section{Discussion}

Recent findings indicate that a high percentage of human breast carcinomas overexpress specific $\mathrm{BN} / \mathrm{GRP}$ receptors, which bind bombesin with high affinity (Halmos et al. 1995, Gugger \& Reubi 1999).
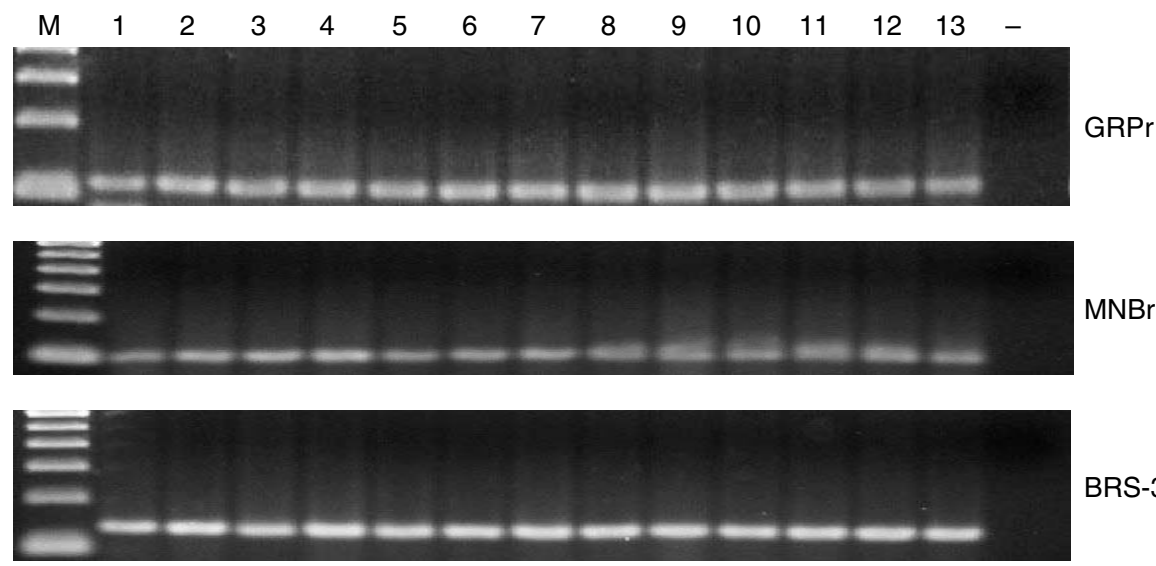

BRS-3

Figure 3 Expression of mRNA for the GRPR, NMBR and BRS-3 in human breast cancer cell lines as revealed by RT-PCR. PCR products were separated on a 1.8\% agarose gel and stained with ethidium bromide. Lane M, 100-base pair DNA ladder; lanes 1-3, MDA-MB-231; lanes 4-6, MDA-MB-435; lanes 7-9, DU-4475; lanes 10-12, MX-1; lane13, MDA-MB-468 (used as a positive control); lane -, total RNA from MDA-MB-231 tumor samples. 
Table 2 Binding characteristics of BN/GRP receptors in MDA-MB-231, DU-4475, MDA-MB-468, MDA-MB-435 and MX-1 human breast cancers xenografted in nude mice. All values represent means \pm S.E. of 3 independent experiments, each carried out in duplicate or triplicate

\begin{tabular}{lccc}
\hline Cell line & Treatment & $\boldsymbol{K}_{\mathbf{d}}$ (nM) & $\begin{array}{c}\mathbf{B}_{\text {max }} \\
\text { (fmol/mg protein) }\end{array}$ \\
\hline MDA-MB-231 & Control & $4.81 \pm 0.73$ & $332.8 \pm 12.6$ \\
DU-4475 & Control & $1.41 \pm 0.03$ & $534.6 \pm 18.1$ \\
MDA-MB-468 & Control & $1.05 \pm 0.06$ & $470.9 \pm 60.9$ \\
MDA-MB-435 & Control & $6.61 \pm 0.14$ & $315.8 \pm 4.3$ \\
MX-1 & Control & $0.57 \pm 0.02$ & $152.1 \pm 33.5$ \\
\hline
\end{tabular}

Binding characteristics were obtained from 12-point displacement experiments. ${ }^{125}$-labeled $\left[\right.$ Tyr $\left.^{4}\right]$-bombesin was used as radioligand.
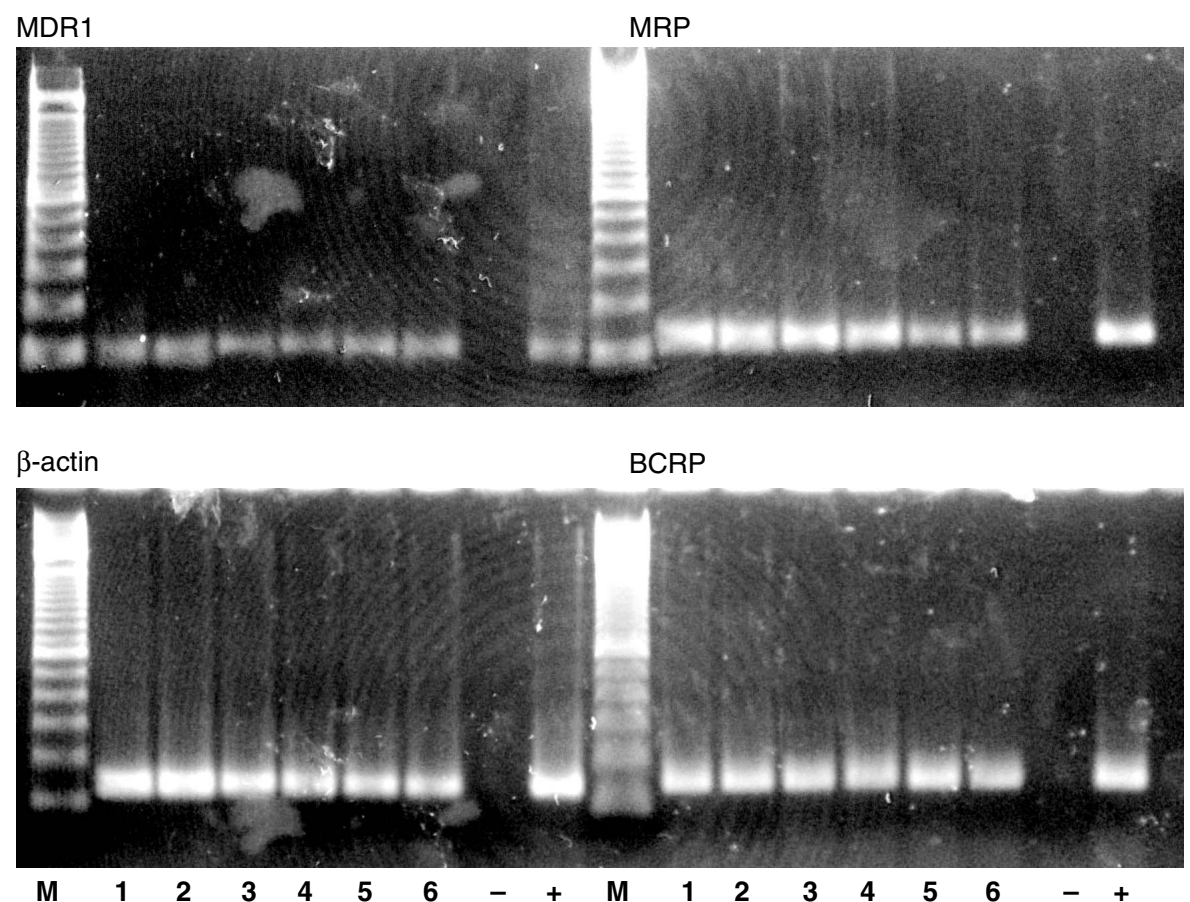

Figure 4 Expression of mRNA for MDR-1, MRP-1 BCRP and $\beta$-actin in human breast cancers as revealed by RT-PCR. PCR products were separated on a $1.8 \%$ agarose gel and stained with ethidium bromide. Specific bands at the expected sizes of $95 \mathrm{bp}$ for MDR-1, $127 \mathrm{bp}$ for MRP-1, $140 \mathrm{bp}$ for BCRP and 140 BP for $\beta$-actin were found in all three human breast cancer cell lines. Lanes 1 and 2 are MDA-MB-231 control samples; lanes 3 and 4 are MDA-MB-435 control samples; lanes 5 and 6 are DU-4475 control samples. The negative control is total RNA The positive controls for MDR-1, MRP-1 and BCRP were the A498 human renal cell cancer cell line, the H4-60 human lung cancer line and the MCF-7 human breast cancer line respectively.

Scintigraphy with radiolabeled bombesin/GRP analogs targeting BN/GRP receptors was successfully used for the detection of primary breast cancers and their lymph node metastases in several clinical studies (Van de Wiele et al. 2000, Scopinaro et al. 2002, Soluri et al. 2003). For the targeted chemotherapy of $\mathrm{BN} / \mathrm{GRP}$ receptor-positive cancers, we developed a cytotoxic hybrid of a bombesin analog linked to
2-pyrrolino-DOX. This conjugate, coded AN-215, retains high affinity to $\mathrm{BN} / \mathrm{GRP}$ receptors and a potent anti-proliferative activity (Nagy et al. 1997). In the current study, we showed that DU-4475, MDAMB-231, MDA-MB-435, MDA-MB-468 and MX-1 breast cancer cell lines express specific, high affinity binding sites for BN and mRNA for the GRPR subtype. All the cell lines used in this study are 
estrogen independent and represent advanced breast cancers that tend to be refractory to treatment. Accordingly, the targeting of $\mathrm{AN}-215$ to $\mathrm{BN} / \mathrm{GRP}$ receptors on these tumors resulted in a significant growth inhibition in all tumor models ranging from 40.7 to $68.4 \%$. The non-targeted cytotoxic radical AN-201 was ineffective in all but one experiment (experiment 4). In experiment 4, we investigated the anti-tumor effect of AN-215 in nude mice xenografted with doxorubicin resistant MX-1 cancers (Arcamone et al. 1997). In this experiment, $\mathrm{AN}-215$ produced the regression of the tumor in 3 of 10 mice and was significantly more efficacious than equimolar doses of AN-201. The unconjugated bombesin analog carrier RC-3094 alone or a mixture of AN-201 and RC-3094 did not significantly suppress the growth of MDAMB-231 cancer xenografts, indicating that the effect of AN-215 is not related to the hormonal activity of the conjugate on bombesin receptors, but rather to the ability of the carrier to deliver AN-201 to cancerous cells. The antitumor effect of AN-215 could be nullified by blocking the tumoral $\mathrm{BN} / \mathrm{GRP}$ receptors with a high dose of the bombesin antagonist RC-3095 prior to the administration of $\mathrm{AN}-215$, which further supports the targeting concept. In experiment 3, MDA-MB-435 cells were injected directly into the mammary fat pads of mice, as this orthotopic model might be a more realistic approach. AN-215 again displayed a significant tumor growth-inhibiting effect, but AN-201 did not. No changes in the concentration of BN/GRP receptors were observed following one and two doses of AN-215 in DU-4475 and MDA-MB-231 breast cancers respectively. Thus a downregulation of the $\mathrm{BN} / \mathrm{GRP}$ receptors, which could decrease the therapeutic effect of AN-215, may not occur.

The toxicities of the cytotoxic bombesin analog AN-215 and its radical AN-201 were compared with respect to mortality, loss of body weight and WBC. The mortality of mice treated with AN-215 was similar to that of controls (6.8 vs $7 \%$ respectively), but after treatment with AN-201 the mortality rate doubled to $15.8 \%$. A moderate, reversible weight loss 8 days after the injection of $\mathrm{AN}-215$ or $\mathrm{AN}-201$ was observed in all experiments. However, this loss was significant only after the injection of $\mathrm{AN}-201$ in two experimental models (experiments 2 and 3). Myelotoxicity is usually the most serious side effect and the dose-limiting factor of chemotherapy. AN-215 did not significantly suppress WBC at any time, while AN-201 significantly lowered WBC 8 days after treatment in all experiments. This indicates that targeted therapy decreases the systemic toxicity. The moderate decrease in WBC after treatment with AN-215 occurred probably due to a high esterase activity in the serum of mice, which can cause the cleavage of the ester bond in AN-215 and release AN-201. As a result, AN-201 in the circulation could reach a level that causes a moderate fall in WBC. It was previously demonstrated in our laboratory that the inhibition of the esterase activity in mice significantly decreases the toxicity of AN-215 (Plonowski et al. 2000). Since the esterase activity is much lower in humans than in mice (Nagy et al. 2000), the myelotoxicity of AN-215 (due to AN-201) is expected to be further reduced in patients. Nevertheless, as GRPR are known to be expressed in the gastrointestinal tract, some side effects on the alimentary system could be anticipated. To evaluate such potential side effects, in previous studies we determined GRPstimulated gastrin secretion in animals after treatment with AN-215 (Plonowski et al. 2000, Szereday et al. 2002). It was found that GRP-stimulated gastrin secretion was not significantly affected after treatment with AN-215. In addition, a recent histopathological evaluation of the gastrointestinal tract after treatment with $\mathrm{AN}-215$ or its radical $\mathrm{AN}-201$ at $250 \mathrm{nmol} / \mathrm{kg}$ revealed only negligible histological changes. Based on these results, it is reasonable to expect relatively minor side effects to the gastrointestinal system.

The increase in the mRNA levels for the multidrug resistance proteins MDR-1, MRP-1 and BCRP after treatment was small after single doses of $\mathrm{AN}-215$ and AN-201, with no major difference after targeted and nontargeted therapy. Thus, a substantially accelerated development of MDR should not be expected to occur after targeted therapy. However, this topic should be reexamined in further studies to determine the MDR protein levels after multiple doses of AN-215.

In conclusion, our results demonstrate that a panel of five human breast cancer cell lines tested expressed receptors for bombesin/GRP and responded to therapy with the targeted cytotoxic bombesin analog AN-215 with a significant tumor inhibition. Further development of the targeted cytotoxic bombesin/GRP analog AN-215 is in progress. This analog should be available for clinical trials in the near future.

\section{Acknowledgements}

This work is dedicated to the late $\mathrm{Dr}$ Ana-Maria Comaru-Schally, who died recently from thyroid cancer, for her intellectual, spiritual and personal contribution and for the inspiration she provided to this project.

The study was supported by the Medical Research Service of the Veterans Affairs Department and by a grant from Zentaris AG, Frankfurt on Main, Germany 
(all to A V S) to Tulane School of Medicine. G K was supported by a fellowship within the post doctorate program of the German Academic Exchange Service (DAAD). We wish to thank Patricia Armatis, Miriam Ducruet and Harold Valerio for excellent experimental assistance and Dudley R Callais for help in preparation of the manuscript. The authors declare that there is no conflict of interest that would prejudice the impartiality of this scientific work.

\section{References}

Abou-Jawde R, Choueiri T, Alemany C \& Mekhail T 2003 An overview of targeted treatments in cancer. Clinical Therapy 25 2121-2137.

Arcamone F, Animati F, Berettoni M, Bigioni M, Capranico G, Casazza AM, Caserini C, Cipollone A, De Cesare M, Franciotti M \& Lombardi P 1997 Doxorubicin disaccharide analogue: apoptosis-related improvement of efficacy in vivo. Journal of the National Cancer Institute 89 1217-1223.

Baselga J, Tripathy D, Mendelsohn J, Baughman S, Benz CC, Dantis L, Sklarin NT, Seidman AD, Hudis CA \& Moore J 1996 Phase II study of weekly intravenous recombinant humanized anti-p185HER2 monoclonal antibody in patients with HER2/neu-overexpressing metastatic breast cancer. Journal of Clinical Oncology 14 737-744.

Bray F, Sankila R, Ferlay J \& Parkin DM 2002 Estimates of cancer incidence and mortality in Europe in 1995. European Journal of Cancer 38 99-166.

Cailleau R, Young R, Olive M \& Reeves WJ Jr 1974 Breast tumor cell lines from pleural effusions. Journal of the National Cancer Institute 53 661-674.

Cailleau R, Olive M \& Cruciger QV 1978 Long-term human breast carcinoma cell lines of metastatic origin: preliminary characterization. In Vitro 14 911-915.

Clark GM, Sledge GW Jr, Osborne CK \& McGuire WL 1987 Survival from first recurrence: relative importance of prognostic factors in 1015 breast cancer patients. Journal of Clinical Oncology 5 55-61.

Cole SP, Bhardwaj G, Gerlach JH, Mackie JE, Grant CE, Almquist KC, Stewart AJ, Kurz EU, Duncan AM \& Deeley RG 1992 Overexpression of a transporter gene in a multidrug-resistant human lung cancer cell line. Science 258 1650-1654.

Filipits M, Malayeri R, Suchomel RW, Pohl G, Stranzl T, Dekan G, Kaider A, Stiglbauer W, Depisch D \& Pirker R 1999 Expression of the multidrug resistance protein (MRP1) in breast cancer. Anticancer Research 19 5043-5049.

Greenberg PA, Hortobagyi GN, Smith TL, Ziegler LD, Frye DK \& Buzdar AU 1996 Long-term follow-up of patients with complete remission following combination chemotherapy for metastatic breast cancer. Journal of Clinical Oncology 14 2197-2205.
Gugger M \& Reubi JC 1999 Gastrin-releasing peptide receptors in non-neoplastic and neoplastic human breast. American Journal of Pathology 155 2067-2076.

Halmos G, Pinski J, Szoke B \& Schally AV 1994 Characterization of bombesin/gastrin-releasing peptide receptors in membranes of MKN45 human gastric cancer. Cancer Letters 85 111-118.

Halmos G, Wittliff JL \& Schally AV 1995 Characterization of bombesin/gastrin-releasing peptide receptors in human breast cancer and their relationship to steroid receptor expression. Cancer Research 55 280-287.

Hortobagyi GN 2003 The curability of breast cancer: present and future. European Journal of Cancer 1 24-34.

Ito K, Fujimori M, Nakata S, Hama Y, Shingu K, Kobayashi S, Tsuchiya S, Kohno K, Kuwano M \& Amano J 1998 Clinical significance of the increased multidrug resistance-associated protein (MRP) gene expression in patients with primary breast cancer. Oncology Research 10 99-109.

Jemal A, Murray T, Ward E, Samuels A, Tiwari RC, Ghafoor A, Feuer EJ \& Thun MJ 2005 Cancer statistics 2005. CA: A Cancer Journal For Clinicians 55 10-30.

Juliano RL \& Ling V 1976 A surface glycoprotein modulating drug permeability in Chinese hamster ovary cell mutants. Biochimica et Biophysica Acta 455 152-162.

Kahan Z, Sun B, Schally AV, Arencibia JM, Cai RZ, Groot K \& Halmos G 2000 Inhibition of growth of MDA-MB-468 estrogen-independent human breast carcinoma by bombesin/gastrin-releasing peptide antagonists RC-3095 and RC-3940-II. Cancer 88 1384-1392.

Keith WN, Stallard S \& Brown R 1990 Expression of mdr1 and gst-pi in human breast tumours: comparison to in vitro chemosensitivity. British Journal of Cancer $\mathbf{6 1}$ $712-716$.

Kiaris H, Schally AV, Nagy A, Sun B, Armatis P \& Szepeshazi K 1999 Targeted cytotoxic analogue of bombesin/gastrin-releasing peptide inhibits the growth of H-69 human small-cell lung carcinoma in nude mice. British Journal of Cancer 81 966-971.

Langlois AJ, Holder WD Jr, Iglehart JD, Nelson-Rees WA, Wells SA Jr \& Bolognesi DP 1979 Morphological and biochemical properties of a new human breast cancer cell line. Cancer Research 39 2604-2613.

Magrath IT 1994 Targeted approaches to cancer therapy. International Journal of Cancer 56 163-166.

Markwalder R \& Reubi JC 1999 Gastrin-releasing peptide receptors in the human prostate: relation to neoplastic transformation. Cancer Research 59 1152-1159.

Nagy A, Armatis P \& Schally AV 1996 High yield conversion of doxorubicin to 2-pyrrolinodoxorubicin, an analog 500-1000 times more potent: structure-activity relationship of daunosamine-modified derivatives of doxorubicin. PNAS 93 2464-2469.

Nagy A, Armatis P, Cai RZ, Szepeshazi K, Halmos G \& Schally AV 1997 Design, synthesis, and in vitro evaluation of cytotoxic analogs of bombesin-like peptides containing 
doxorubicin or its intensely potent derivative, 2-pyrrolinodoxorubicin. PNAS 94 652-656.

Nagy A, Plonowski A \& Schally AV 2000 Stability of cytotoxic luteinizing hormone-releasing hormone conjugate (AN-152) containing doxorubicin 14-O-hemiglutarate in mouse and human serum in vitro: implications for the design of preclinical studies. PNAS $97829-834$.

Nooter K, Brutel de la Riviere G, Look MP, van Wingerden KE, Henzen-Logmans SC, Scheper RJ, Flens MJ, Klijn JG, Stoter G \& Foekens JA 1997 The prognostic significance of expression of the multidrug resistanceassociated protein (MRP) in primary breast cancer. British Journal of Cancer 76 486-493.

Osborne CK 1998 Tamoxifen in the treatment of breast cancer. New England Journal of Medicine 339 1609-1618.

Pfaffl MW 2001 A new mathematical model for relative quantification in real-time RT-PCR. Nucleic Acids Research 29 e45.

Plonowski A, Nagy A, Schally AV, Sun B, Groot K \& Halmos G 2000 In vivo inhibition of PC-3 human androgen-independent prostate cancer by a targeted cytotoxic bombesin analogue, $\mathrm{AN}-215$. International Journal of Cancer $\mathbf{8 8}$ 652-657.

Powles TJ, Coombes RC, Smith IE, Jones JM, Ford HT \& Gazet JC 1980 Failure of chemotherapy to prolong survival in a group of patients with metastatic breast cancer. Lancet 1 580-582.

Rasmussen R (2001) Quantification on the LightCycler. In Rapid Cycle Real-time PCR, Methods and Applications, pp 21-34. Eds SWC Meuer \& K Nakagawara. Heidelberg: Springer Press.

Ross DD, Yang W, Abruzzo LV, Dalton WS, Schneider E, Lage H, Dietel M, Greenberger L, Cole SP \& Doyle LA 1999 Atypical multidrug resistance: breast cancer resistance protein messenger RNA expression in mitoxantrone-selected cell lines. Journal of the National Cancer Institute 91 429-433.

Schally AV \& Nagy A 1999 Cancer chemotherapy based on targeting of cytotoxic peptide conjugates to their receptors on tumors. European Journal of Endocrinology 141 1-14.

Schally AV \& Nagy A 2003 New approaches to treatment of various cancers based on cytotoxic analogs of LHRH, somatostatin and bombesin. Life Sciences 72 2305-2320.

Schally AV \& Nagy A 2004 Chemotherapy targeted to cancers through tumoral hormone receptors. Trends in Endocrinology and Metabolism 15 300-310.

Schally AV, Comaru-Schally AM, Nagy A, Kovacs M, Szepeshazi K, Plonowski A, Varga JL \& Halmos G
2001 Hypothalamic hormones and cancer. Frontiers in Neuroendocrinology 22 248-291.

Schneider J, Bak M, Efferth T, Kaufmann M, Mattern J \& Volm M 1989 P-glycoprotein expression in treated and untreated human breast cancer. British Journal of Cancer $60815-818$.

Scopinaro F, Varvarigou AD, Ussof W, De Vincentis G, Sourlingas TG, Evangelatos GP, Datsteris J \& Archimandritis SC 2002 Technetium labeled bombesinlike peptide: preliminary report on breast cancer uptake in patients. Cancer Biotherapy and Radiopharmaceuticals 17 327-335.

Soluri A, Scopinaro F, De Vincentis G, Varvarigou A, Scafe R, Massa R, Schillaci O, Spanu A \& David V 2003 99MTC [13LEU] bombesin and a new gamma camera, the imaging probe, are able to guide mammotome breast biopsy. Anticancer Research 23 2139-2142.

Sun B, Halmos G, Schally AV, Wang X \& Martinez M 2000 Presence of receptors for bombesin/gastrin-releasing peptide and mRNA for three receptor subtypes in human prostate cancers. Prostate 42 295-303.

Szereday Z, Schally AV, Nagy A, Plonowski A, Bajo AM, Halmos G, Szepeshazi K \& Groot K 2002 Effective treatment of experimental U-87MG human glioblastoma in nude mice with a targeted cytotoxic bombesin analogue, AN-215. British Journal of Cancer 86 $1322-1327$.

Todd M, Shoag M \& Cadman E 1983 Survival of women with metastatic breast cancer at Yale from 1920 to 1980. Journal of Clinical Oncology 1 406-408.

Trail PA, King HD \& Dubowchik GM 2003 Monoclonal antibody drug immunoconjugates for targeted treatment of cancer. Cancer Immunology, Immunotherapy 52 328-337.

UKCCCR 1998 United Kingdom Co-ordinating Committee on Cancer Research (UKCCCR) Guidelines for the Welfare of Animals in Experimental Neoplasia, 2nd ed. British Journal of Cancer 77 1-10.

Van de Wiele C, Dumont F, Vanden Broecke R, Oosterlinck W, Cocquyt V, Serreyn R, Peers S, Thornback J, Slegers G \& Dierckx RA 2000 Technetium-99m RP527, a GRP analogue for visualisation of GRP receptor-expressing malignancies: a feasibility study. European Journal of Nuclear Medicine 27 1694-1699.

Wang QJ, Knezetic JA, Schally AV, Pour PM \& Adrian TE 1996 Bombesin may stimulate proliferation of human pancreatic cancer cells through an autocrine pathway. International Journal of Cancer $\mathbf{6 8} 528-534$. 
